\title{
PROTECTIVE EFFECT OF DEXMEDETOMIDINE COMBINED WITH ULINASTATIN ON MYOCARDIUM IN PATIENTS UNDERGOING VALVE REPLACEMENT
}

\author{
YURU ZHAN $^{1}{ }^{*}$, HONGWEI ZHANG ${ }^{1}$, ZHENDONG HAN $^{2}$ \\ ${ }^{I}$ Department of Anesthesiology, The Third Affiliated Hospital of Qiqihar Medical University, Qiqihar City 161000, China \\ ${ }^{2}$ Department of Cardiothoracic Surgery, The Third Affiliated Hospital of Qiqihar Medical University, Qiqihar City 161000, China \\ *corresponding author: zhanyr_3ahqmu@163.com \\ Manuscript received: April 2018
}

\begin{abstract}
The aim of the study was to evaluate the myocardial protective effect of dexmedetomidine (Dex) combined with ulinastatin in patients undergoing heart valve replacement (HVR). Thirty-six patients undergoing cardiopulmonary bypass (CPB) were randomly divided into control group (group C), Dex group (group D), ulinastatin group (group U), and Dex combined with ulinastatin group (group B), 9 patients per group. Hemodynamic changes were monitored in all patients. From each patient 3 $\mathrm{mL}$ of blood was collected from the internal jugular vein at 30 minutes after anaesthesia induction, 30 minutes after rewarming, 30 minutes, 4 hours and 24 hours after stopping anaesthesia. The concentrations of tumour necrosis factor- $\alpha$ (TNF- $\alpha$ ), interleukin-6 (IL-6), plasma S100 $\beta$ protein and malondialdehyde (MDA) were measured. The results showed that there was no significant difference in regional arterial blood pressure, central venous blood pressure, heart rate and oxygen saturation between the four groups $(\mathrm{p}>0.05)$. The concentrations of TNF- $\alpha$, IL-6, MDA and S100 $\beta$ in blood had no significant difference immediately after anaesthesia induction $(\mathrm{p}>0.05)$; 30 minutes after anaesthesia induction, 30 minutes after rewarming, 30 minutes, 4 hours and 24 hours after stopping anaesthesia, the concentration of TNF- $\alpha$, IL-6, MDA and $\mathrm{S} 100 \beta$ in group D and U were significantly lower than those in group C, while those in group B were significantly lower than those in groups D and $U(\mathrm{p}<0.05)$. In conclusion, Dex combined with ulinastatin can alleviate myocardial injury in patients undergoing cardiopulmonary bypass valve replacement, and has good myocardial protection, superior to the dexmedetomidine or ulinastatin alone.
\end{abstract}

\section{Rezumat}

Scopul studiului a fost evaluarea efectului protector miocardic al dexmedetomidinei (Dex) combinată cu ulinastatin la pacienții supuși înlocuirii valvei cardiace (HVR). Treizeci și șase de pacienți care au suferit bypass cardiopulmonar (CPB) au fost înrolați aleatoriu în grupul de control (grupul C), grupul Dex (grupul D), grupul ulinastatin (grupul U) și Dex combinat cu ulinastatin (grupul B). Modificările hemodinamice au fost monitorizate la toți pacienții. De la fiecare pacient, $3 \mathrm{~mL}$ de sânge au fost colectați din vena jugulară internă la 30 de minute după inducerea anesteziei, 30 de minute după rewarming, 30 de minute, 4 ore și 24 de ore după oprirea anesteziei. S-au măsurat concentrațiile factorului de necroză tumorală- $\alpha($ TNF- $\alpha)$, interleukină-6 (IL-6), proteină S100 din plasmă şi malondialdehidă (MDA). Rezultatele au arătat că nu există diferențe semnificative în tensiunea arterială regională, tensiunea arterială venoasă centrală, ritmul cardiac și saturația oxigenului între cele patru grupuri $(p>0,05)$. Concentrațiile de TNF- $\alpha$, IL-6, MDA și S100 $\beta$ din sânge nu au avut o diferență semnificativă imediat după inducerea anesteziei ( $p>0,05)$. Concentrațiile de TNF- $\alpha$, IL-6, MDA și S100 $\beta$ în grupurile D și U, la 30 de minute după inducerea anesteziei, 30 minute după rewarming, 4 ore și 24 de ore după oprirea anesteziei, au fost semnificativ mai scăzute decât cele din grupul C , in timp ce pentru grupul B au fost semnificativ mai mici decât grupurile D și U (p $<0,05)$. În concluzie, Dex combinat cu ulinastatin poate ameliora leziunea miocardică la pacienții supuşi bypassului cardiopulmonar și prezintă o protecție benefică asupra miocardului, superioară dexmedetomidinei sau ulinastatinei administrate singular.

Keywords: dexmedetomidine, ulinastatin, heart valve replacement, cardiopulmonary bypass, myocardial protection

\section{Introduction}

Valvular heart disease (VHD) is a common clinical disease and it highly occurs among the elderly. Heart valve replacement (HVR) under cardiopulmonary bypass (CPB) is often used for treatment of VHD. HVR is usually performed under extracorporeal circulation [1]. Circulation and aortic blockade can lead to myocardial hypoxia and accumulation of local metabolites. Opening the aorta can easily lead to myocardial ischemia-reperfusion injury, and even cause to irreversible myocardial injury and necrosis. Several therapeutic options were tried for preventing myocardial ischemia-reperfusion injury $[2,3]$

Dexmedetomidine (Dex) is a new type of highly selective and specific $\alpha 2$-adrenergic receptor agonist. It has a half-life of about 6 minutes and an elimination half-life of about 2.0 hours. Dex has a high affinity 
FARMACIA, 2019, Vol. 67, 3

for $\alpha$-2a subtype of adrenergic receptor. FDA (Food and Drug Administration) approved it in 2008 for sedation in non-intubated patients [4]. It has been widely used in Intensive Care Unit (ICU) sedation and procedural sedation. Studies have shown that Dex plays a protective role in the nervous system by reducing the levels of catecholamine in ischemic and hypoxic tissues, inhibiting intracellular calcium influx, and reducing the release and activity of excitatory neurotransmitters such as glutamate $[4,5]$.

Ulinastatin is a tryptase inhibitor which can inhibit the activity of various proteolytic enzymes extracted from fresh human urine. Ulinastatin can inhibit trypsin, neutrophil elastase and other serine proteases, hyaluronidase and cathepsin $\mathrm{G}[6,7,8,9]$. It can also inhibit cascade reaction of waterfall-like inflammation, scavenge oxygen free radicals, regulate immune function, and protect various organ functions. The use of Dex and ulinastatin alone in HVR surgery has attracted extensive attention $[10,11]$. However, there are few reports on whether the combination of the two drugs has synergistic or enhanced effects, whether it can further reduce the inflammatory reactions, oxygen free radicals and lipid peroxidation during cardiopulmonary bypass, and whether it can play a better role in myocardial protection. In this study patients undergoing HVR under CPB were treated with ulinastatin alone or in combination with Dex, in order to explore whether they have synergistic or enhanced effects on myocardial protection, and to provide new ideas for improving cardiac dysfunction after surgery.

\section{Materials and Methods}

Patients and study protocol

Thirty-six patients, 23 males and 13 females, who undergone HVR under $\mathrm{CPB}$ in the cardiac surgery of The Third Affiliated Hospital of Qiqihar Medical University, China, between October 2014 and October 2018 were included in the study. The patients were randomly divided into four experimental groups (9 patients in each group) as follows: Group $\mathrm{C}$ or control group that received saline solution instead of testing solutions after induction of anaesthesia, after rewarming, and 10 minutes after stopping anaesthesia; Group $\mathrm{U}$ or the ulinastatin group that received $10000 \mathrm{U} / \mathrm{kg}$ ulinastatin infused for 10 minutes using a micro-infusion pump (Chongqing Jinhuzi Education Science and Technology Company, China) immediately after induction of anaesthesia followed by $5000 \mathrm{U} / \mathrm{kg}$ ulinastatin after rewarming and 10 minutes after stopping anaesthesia; Group D or the Dex group that received $1 \mu \mathrm{g} / \mathrm{kg}$ Dex after induction of anaesthesia, and then maintained at a concentration rate of 0.5 $\mu \mathrm{g} / \mathrm{kg} / \mathrm{h}$ until the end of the surgery; Group B or the Dex combined with ulinastatin group that received $10000 \mathrm{U} / \mathrm{kg}$ ulinastatin plus $1 \mu \mathrm{g} / \mathrm{kg}$ Dex after the induction of anaesthesia, followed Dex at a concentration rate of $0.5 \mu \mathrm{g} / \mathrm{kg} / \mathrm{h}$ until the end of the surgery associated with $5000 \mathrm{U} / \mathrm{kg}$ ulinastatin rewarming and 10 minutes after stopping anaesthesia.

All subjects included in the study had signed an informed consent for participation and the study design was approved by the Ethics Committee of The Third Affiliated Hospital of Qiqihar Medical University, China.

Inclusion criteria: American Society of Anaesthesiologists (ASA) cardiac function I - II [1]; age: 25 - 45; preoperative liver and kidney function normal; haemoglobin $>100 \mathrm{~g} / \mathrm{L}$, haematocrit $>30 \%$, coagulation function normal; postoperative hemodynamic stability, successful extraction of tracheal intubation.

Exclusion criteria: pre-operative history of endocrine and psychiatric diseases; pre-operative history of hormone and antibiotic use within a week; secondary surgery patients; drug use or drug allergy related research; pre-operative heart and lung failure.

Drugs and reagents

Ulinastatin Injection (www.techpool.com,China); Dexmedetomidine Hydrochloride Injection (Jiangsu Hengrui Pharmaceutical Co., LTD, China); TNF- $\alpha$ kit (Beijing Baioleibo Technology Co., Ltd., China), microporous plate (Hangzhou Ruicheng Instrument Co., Ltd., China), human TNF- $\alpha$ antibody label HRP (horse radish peroxidase); TMB (trimethylbenzene); IL-6 kit (Beijing Baioleibo Technology Co., Ltd., China); S100 $\beta$ protein kit (Beijing Baioleibo Technology Co., Ltd., China); MDA kit (Beijing Baioleibo Technology Co., Ltd., China)

Serum collection

$3 \mathrm{~mL}$ blood samples were collected from the internal jugular vein at five time points: 30 minutes after anaesthesia induction (T1), 30 minutes after rewarming (T2), 30 minutes (T3), 4 hours (T4) and 24 hours (T5) after stopping anaesthesia. The blood samples were centrifuged for 10 minutes at $2500 \mathrm{r} / \mathrm{min}$ in a TD5A-WS centrifuge (Hunan Xiangyi Laboratory Instrument Development Co., Ltd., China) and then the serum was collected and kept at $-80^{\circ} \mathrm{C}$ till further analysis. The concentrations of tumour necrosis factor- $\alpha$ (TNF- $\alpha$ ), interleukin-6 (IL-6), plasma S100 $\beta$ protein and malondialdehyde (MDA) were determined by enzyme-linked immunosorbent assay (ELISA).

Determination of serum $T N F-\alpha$ levels

The level of human TNF- $\alpha$ in serum was determined by ELISA using TNF- $\alpha$ kit (Beijing Baioleibo Tech. Co., Ltd., China) according to manufacturer instructions. The following reagents were used: TNF- $\alpha$ antibody coated with microporous plate (Hangzhou Ruicheng Instrument Co., Ltd., China), human TNF- $\alpha$ antibody labelled by HRP (horse radish peroxidase); TMB (Trimethylbenzene).

Determination of serum IL-6 levels

The level of IL- 6 in serum was determined by ELISA using a IL-6 kit (Beijing Baioleibo Technology Co., 
Ltd., China) according the manufacturer instructions. The following reagents were used: purified human IL-6 antibody, HRP-labelled IL-6 antibody; TMB.

Determination of serum $S 100 \beta$ levels

The level of $\mathrm{S} 100 \beta$ in serum was determined by ELISA using an S100 $\beta$ protein kit (Beijing Baioleibo Tech. Co., Ltd., China) according to manufacturer instructions. The following reagents were used: purified human S100 $\beta$ antibody, HRP labelled S100 $\beta$ antibody, TMB.

Determination of serum MDA

The level of MDA in serum was determined by ELISA using a MDA kit (Beijing Baioleibo Technology Co., Ltd., China) according to manufacturer instructions. The following reagents were used: MDA antibody, HRP-labelled MDA antibody, TMB.

Statistical analysis

The measurements were expressed as mean \pm standard deviation. Single factor analysis of variance was used for intra-group comparison and LSD (Least Significant
Difference) method was used to compare the differences between different time points in each group. The data of each group were compared by repeated two-factor variance analysis tools, and the data of different time points were compared using Bonferroni correction method. SPSS17.0 statistical software (IBM Company, USA) was used for statistical analysis. A value of $\mathrm{p}<0.05$ suggests statistical significance.

\section{Results and Discussion}

Comparisons of bleeding volume, urine volume, crystal infusion volume, and colloid infusion volume between the groups

The data of bleeding volume, urine volume, crystal infusion volume, and colloid infusion volume during operation in the four groups were monitored and compared, and there was no significant difference between the groups $(\mathrm{p}>0.05)$, as shown in Table I.

Table I

Comparisons of surgical status of patients $(n=9)$

\begin{tabular}{cccccc}
\hline Group & Transfusion volume & Bleeding volume & Urine volume & CPB time & Operative time \\
\cline { 2 - 5 } & $(\mathrm{mL})$ & $(\mathrm{mL})$ & $(\mathrm{mL})$ & $(\mathrm{min})$ & $(\mathrm{min})$ \\
Group C & $50 \pm 5.9$ & $35.5 \pm 8.8$ & $127.7 \pm 30.3$ & $47.2 \pm 5.6$ & $157.2 \pm 15.3$ \\
Group U & $49.2 \pm 4.4$ & $40.3 \pm 7.2$ & $117.1 \pm 28.4$ & $50.4 \pm 2.8$ & $147.7 \pm 16.3$ \\
Group D & $48.1 \pm 8.2$ & $38.3 \pm 6.4$ & $106.3 \pm 21.3$ & $59.3 \pm 3.3$ & $166.9 \pm 12.2$ \\
Group B & $53.4 \pm 7.5$ & $37.4 \pm 5.7$ & $123.3 \pm 33.1$ & $53.6 \pm 4.2$ & $154.6 \pm 17.9$ \\
\hline
\end{tabular}

Comparison of serum TNF- $\alpha$ concentration at different time points between the groups

Compared with group $\mathrm{C}$, the serum TNF- $\alpha$ concentration in group $\mathrm{U}$ and group $\mathrm{D}$ decreased slightly at $\mathrm{T} 1$, but without reaching the statistical significance $(\mathrm{p}>$ 0.05 ), while at T2, T3, T4 and T5 the level of TNF- $\alpha$ was significantly decreased compared to control in both groups $\mathrm{U}$ and $\mathrm{D}(\mathrm{p}<0.05)$. Compared with group $\mathrm{C}$, the serum TNF- $\alpha$ concentration in group $\mathrm{B}$ decreased significantly from $\mathrm{T} 1$ to $\mathrm{T} 5(\mathrm{p}<0.05)$.

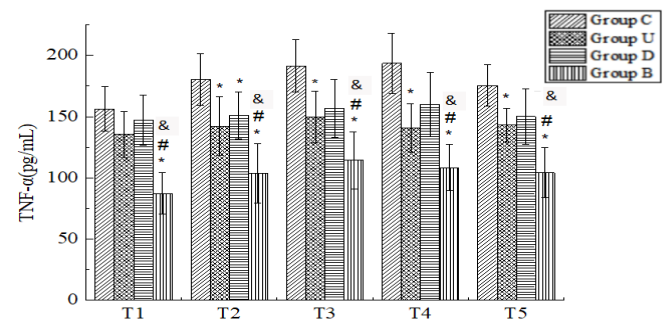

Figure 1.

ViscoComparison of serum TNF- $\alpha$ concentration in different groups at different time points

${ }^{*} \mathrm{p}<0.05$ compared with group $\mathrm{C} ;{ }^{*} \mathrm{p}<0.05$ compared with group U; $\&_{p}<0.05$ compared with group and group D. T1:30 minutes after anaesthesia induction; T2: 30 minutes after rewarming; T3: 30 minutes after stopping anaesthesia; T4: 4 hours after stopping anaesthesia; T5: 24 hours after stopping anaesthesia

Compared with group D, the plasma TNF- $\alpha$ concentration in group $\mathrm{B}$ decreased significantly at each time point $(\mathrm{p}<0.05)$. Compared with group $\mathrm{U}$, the plasma TNF- $\alpha$ concentration in group B also decreased significantly at each time point $(p<0.05)$ (Figure 1).

Comparison of serum IL-6 levels at different time points between the groups

Compared with group C, the serum IL-6 concentration in group $\mathrm{U}$ and group $\mathrm{D}$ decreased slightly at $\mathrm{T} 1$, but without any statistical difference $(\mathrm{p}>0.05)$, and continue to significantly decrease at $\mathrm{T} 2, \mathrm{~T} 3, \mathrm{~T} 4$ and T5 $(\mathrm{p}<0.05)$.

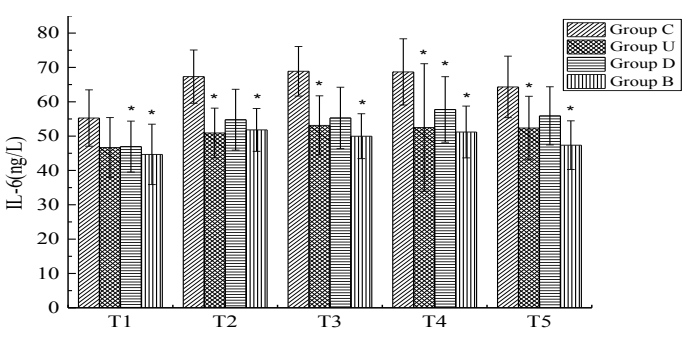

Figure 2.

Comparison of serum IL-6 concentrations in different groups at different time points *p $<0.05$ compared with group C. T1:30 minutes after anaesthesia induction; T2: 30 minutes after rewarming; T3: 30 minutes after stopping anaesthesia; T4: 4 hours after stopping anaesthesia; T5: 24 hours after stopping anaesthesia

Compared with group C, the serum IL-6 concentration in group B decreased significantly at 
FARMACIA, 2019, Vol. 67, 3

each time point $(p<0.05)$. In group $B$ the serum IL-6 concentration decreased slightly at each time point compared with group $U$ and group $D$ but without reaching the statistical significance $(p>0.05)$ (Figure 2).

Comparison of serum $S 100 \beta$ protein concentration at different time points between the groups

Compared with group $\mathrm{C}$, the concentration of plasma $\mathrm{S} 100 \beta$ protein in group $\mathrm{U}$, group $\mathrm{D}$ and group B decreased significantly at each time point $(p<0.05)$. In group B the concentration of plasma $\mathrm{S} 100 \beta$ protein decreased significantly at each time point compared with group $U$ and group $D(p<0.05)$ (Figure 3$)$

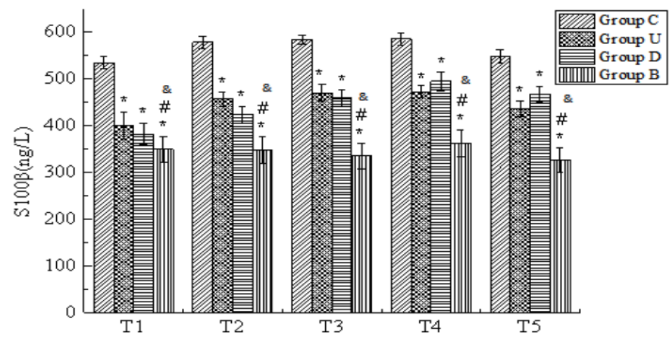

Figure 3.

Comparison of serum S100 $\beta$ concentrations in different groups at different time points $* \mathrm{p}<0.05$ compared with group $\mathrm{C}, \mathrm{p} p<0.05$ compared with group $\mathrm{U}$, ${ }^{\&} \mathrm{p}<0.05$ compared with group D T1:30 minutes after anaesthesia induction; T2: 30 minutes after rewarming; T3: 30 minutes after stopping anaesthesia; T4: 4 hours after stopping anaesthesia; T5: 24 hours after stopping anaesthesia

Comparison of serum MDA concentration at different time points between the groups

Compared with group $\mathrm{C}$, serum MDA concentration in group $\mathrm{U}$ did not change significantly at each time point $(p>0.05)$. In group D the serum MDA concentration decreased significantly compared with group $\mathrm{C}$ for each time point $(p<0.05)$. The same trend as for the group D was also observed for the group B that significantly decreased at each time point compared to group $\mathrm{C}$ and group $\mathrm{U}(\mathrm{p}<0.05)$ (Figure 4$)$.

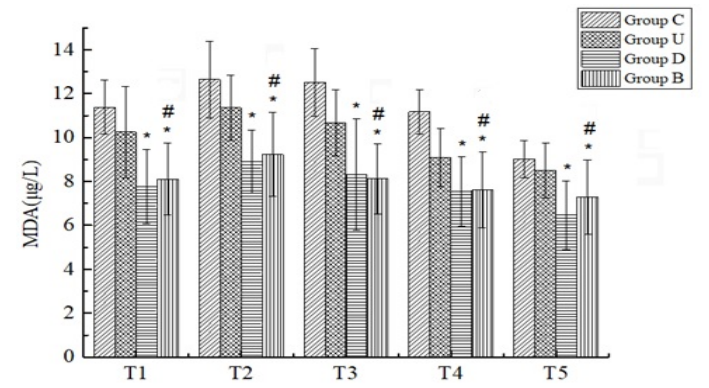

Figure 4.

Comparison of serum MDA concentrations in different groups at different time points ${ }^{*} \mathrm{p}<0.05$ compared with group $\mathrm{C} ;{ }^{*} \mathrm{p}<0.05$ compared with the group U. T1:30 minutes after anaesthesia induction; T2: 30 minutes after rewarming; T3: 30 minutes after stopping anaesthesia; T4: 4 hours after stopping anaesthesia; T5: 24 hours after stopping anaesthesia
HVR uses CPB technology, and cardiac ischemiareperfusion injury, micro-embolism and oxygen free radicals can trigger systemic inflammatory responses $[12,13]$. The serum concentration of inflammatory factors TNF- $\alpha$, IL- 6 and MDA gradually increases after the beginning of $\mathrm{CPB}$, peaks at 4 hours after the end of $\mathrm{CPB}$, and then decreases gradually, indicating that $\mathrm{CPB}$ itself can cause strong release of TNF- $\alpha$, IL-6 and MDA [14].

Dex regulates the function of immune system and makes macrophages and monocytes produce cytokines to play an anti-inflammatory role in stress response $[15,16]$. The serum levels of TNF- $\alpha$, IL-6 and MDA in the control group (group C) were higher than those after anaesthesia induction from the beginning till the end of extracorporeal circulation for 4 hours, while the plasma levels of $\mathrm{S} 100 \beta$ protein, TNF- $\alpha$, IL-6 and MDA in the Dex group (group D) were significantly lower than those in the anaesthesia induction group. These results suggest that Dex may play a protective role in myocardial ischemiareperfusion injury by lowering the level of inflammatory mediators [17].

Ulinastatin can alleviate local inflammation, inhibit the release of oxygen free radicals, lipid peroxidation and elastase [18], reduce capillary permeability and myocardial ischemia-reperfusion injury, and reduce the incidence of myocardial inflammation after ischemia-reperfusion $[19,20]$. The serum levels of TNF- $\alpha$, IL-6 and MDA in the control group (group C) increased from the beginning of CPB till the end of $\mathrm{CPB}$ within 4 hours after induction of anaesthesia. However, the serum levels of TNF- $\alpha$, IL- 6 and MDA in ulinastatin group (group $U$ ) were significantly lower than those in the control group (group C) within 4 hours from the beginning of $\mathrm{CPB}$ till the end of CPB, suggesting that ulinastatin can alleviate cardiac cell injury by inhibiting inflammatory response [21].

The combination of ulinastatin and Dex (group B) can reduce the concentration of TNF- $\alpha$, IL- 6 , MDA and $\mathrm{S} 100 \beta$ at different time points in serum compared with the single use of ulinastatin (group U) and Dex (group D). It was shown that the combination of ulinastatin and Dex can reduce the stress response to a certain extent, and reduce the damage of inflammatory mediators to cardiac cells of patients [22]. They have synergistic effect through different ways, and further play the role of organ protection.

\section{Conclusions}

In conclusion, dexmetomidine combined with ulinastatin can alleviate myocardial injury in patients undergoing $\mathrm{CPB}$, and has good myocardial protection properties. 
FARMACIA, 2019, Vol. 67, 3

\section{Conflicts of interest}

The author declares no conflicts of interest relevant to the article.

\section{References}

1. Ljungberg J, Johansson B, Engstrom KG, Albertsson E, Holmer P, Norberg M, Bergdahl IA, Soderberg $\mathrm{S}$, Traditional cardiovascular risk factors and their relation to future surgery for valvular heart disease or ascending aortic disease: A case-referent study. $J$ Am Heart Assoc., 2017; 6(5): 1-12.

2. Tabrizian K, Shahriari Z, Rezaee R, Jahantigh H, Bagheri G, Tsarouhas K, Docea AO, Tsatsakis A, Hashemzaei M, Cardioprotective effects of insulin on carbon monoxide-induced toxicity in male rats. Hum Exp Toxicol., 2019; 38(1): 148-154.

3. Hashemzaei M, Barani AK, Iranshahi M, Rezaee R, Tsarouhas K, Tsatsakis AM, Wilks MF, Tabrizian $\mathrm{K}$, Effects of resveratrol on carbon monoxideinduced cardiotoxicity in rats. Environ Toxicol Pharmacol., 2016; 46: 110-115.

4. Cho JS, Shim JK, Soh S, Kim MK, Kwak YL, Perioperative dexmedetomidine reduces the incidence and severity of acute kidney injury following valvular heart surgery. Kidney Int., 2016; 89(3): 693-700.

5. Zhang YS, Jin LJ, Zhou X, Liu Y, Li Y, Wen LY, Effect of dexmedetomidine on stress reactions and cellular immune function of patients in perioperative period following radial resection for rectal carcinoma. J Biol Regul Homeost Agents, 2018; 32(1): 139-145.

6. Feng C, Su X, Chen LI, Zhou X, Li B, Wang LL, Lv FQ, Li TS, Ulinastatin enhances the therapeutic effect of intraperitoneal lavage on severe acute pancreatitis in rats. Exp Ther Med., 2015; 9(5): 1651-1655.

7. Hu HX, Xu DH, Ju WN, Ma C, Wang X, Liu XL, Neuroprotection of ulinastatin on transient cerebral ischemia via antioxidative mechanisms. $J$ Biol Regul Homeost Agents, 2018; 32(2): 283-288.

8. Xing HF, Wen H, Wang DJ, Wang HH, Zhao M, Effect of ulinastatin combined with haemodialysis on severe acute pancreatitis. Farmacia, 2017; 65(5): 714-719.

9. Hu HX, Zhu MQ, Sun YC, Ma C, Wang X, Liu $\mathrm{XL}$, Xuebijing enhances neuroprotective effects of ulinastatin on transient cerebral ischemia via Nrf2are signal pathways in the hippocampus. $J$ Biol Regul Homeost Agents, 2018; 32(5): 1143-1149.

10. Riquelme JA, Westermeier F, Hall AR, Vicencio JM, Pedrozo Z, Ibacache M, Fuenzalida B, Sobrevia L, Davidson SM, Yellon DM, Sanchez G, Lavandero $\mathrm{S}$, Dexmedetomidine protects the heart against ischemia-reperfusion injury by an endothelial eNOS/NO dependent mechanism. Pharmacol Res., 2016; 103: 318-327.

11. Xiao J, Zhu X, Ji G, Yang Q, Kang B, Zhao J, Yao F, Wu L, Ni X, Wang Z, Ulinastatin protects cardiomyocytes against ischemiareperfusion injury by regulating autophagy through mTOR activation. Mol Med Rep., 2014; 10(4): 1949-1953.
12. Konecny J, Klvacek A, Simek M, Lonsky V, Santavy $\mathrm{P}$, Complex gunshot injury to the heart as a consequence of suicide attempt in a schizophrenic patient. Int J Surg Case Rep., 2016; 24(C): 80-82.

13. Allareddy V, Prakasam S, Rampa S, Stein K, Nalliah RP, Allareddy V, Rengasamy Venugopalan $\mathrm{S}$, Impact of periapical abscess on infectious complications in patients undergoing extracorporeal circulation auxiliary to open-heart surgical procedures. J Evid Based Dent Pract., 2017; 17(1): 13-22.

14. Carmona P, Mateo E, Montoro A, Alós L, Coret M, Errando CL, Llagunes J, De Andrés J, [Evaluation of postoperative myocardial injury by heart-type fatty acid-binding protein in off-pump coronary artery bypass grafting surgery. Rev Esp Anestesiol Reanim., 2015; 62(1): 3-9.

15. Shi X, Tasdogan A, Huang F, Hu Z, Morrison SJ DeBerardinis RJ, The abundance of metabolites related to protein methylation correlates with the metastatic capacity of human melanoma xenografts. Sci Adv., 2017; 3(11): 1-14.

16. Schmidt K, Zhang Q, Tasdogan A, Petzold A, Dahl A, Arneth BM, Slany R, Fehling HJ, Kranz A, Stewart AF, Anastassiadis K, The H3K4 methyltransferase Setd $1 \mathrm{~b}$ is essential for hematopoietic stem and progenitor cell homeostasis in mice. eLife, 2018, 7: 1-30.

17. Chen S, Hua F, Lu J, Jiang Y, Tang Y, Tao L, Zou B, $\mathrm{Wu} \mathrm{Q}$, Effect of dexmedetomidine on myocardial ischemia-reperfusion injury. Int J Clin Exp Med., 2015; 8(11): 21166-21172.

18. Piazza O, Staiano RI, De Robertis E, Conti G, Di Crescenzo V, Loffredo S, Marone G, Marinosci GZ, Cataldi MM, Effect of $\alpha 2$-adrenergic agonists and antagonists on cytokine release from human lung macrophages cultured in vitro. Transl Med UniSa., 2016; 15: 67-73.

19. Huang SQ, Zhang J, Zhang XX, Liu L, Yu Y, Kang $\mathrm{XH}, \mathrm{Wu} \mathrm{XM}, \mathrm{Zhu} \mathrm{SM}$, Can dexmedetomidine improve arterial oxygenation and intrapulmonary shunt during one-lung ventilation in adults undergoing thoracic surgery? A meta-analysis of randomized, placebo-controlled trials. Chin Med J (Engl)., 2017; 130(14): 1707-1714.

20. Varrica A, Satriano A, Gavilanes ADW, Zimmermann LJ, Vles HJS, Pluchinotta F, Anastasia L, Giamberti A, Baryshnikova E, Gazzolo D, S100B increases in cyanotic versus noncyanotic infants undergoing heart surgery and cardiopulmonary bypass (CPB). $J$ Matern Fetal Neonatal Med., 2019; 32(7): 1117-1123.

21. Hocaoğlu N, Murat N, Micılı SC, Aydın B, Ergür BU, Kalkan Ş, Correlation between amitriptylineinduced cardiotoxic effects and cardiac $\mathrm{S} 100 \mathrm{~b}$ protein in isolated rat hearts. Balkan Med J., 2016; 33(6): 681-687.

22. Trakas E, Domnina Y, Panigrahy A, Baust T, Callahan PM, Morell VO, Munoz R, Bell MJ, Sanchez-deToledo J, Serum neuronal biomarkers in neonates with congenital heart disease undergoing cardiac surgery. Pediatr Neurol., 2017; 72: 56-61 